RESEARCH ARTICLE

\title{
Arthropod Diversity of Pomegranate Crop under High Density Planting in Tamil Nadu
}

\section{K.Elango $0^{1^{*}}$ and S. Sridharan ${ }^{2}$}

${ }^{1}$ (Agricultural Entomology), Horticultural Research Station, Kodaikanal - 624103

2Department of Agricultural Entomology, Centre for Plant Protection Studies, Tamil Nadu Agricultural University, Coimbatore - 641 003,

\begin{abstract}
Received : $16^{\text {th }}$ November, 2020

Revised : $23^{\text {rd }}$ November, 2020

Revised : $03^{\text {rd }}$ December, 2020

Accepted : $17^{\text {th }}$ December, 2020

Insects associated with pomegranate (Punica granatum L.), was observed from 2015 to 2016 in four major pomegranate growing districts of Tamil Nadu viz., Coimbatore, Erode, Tiruppur and Karurat monthly intervals. A total of 31 species under two genera and sixteen families of six orders was documented. In addition, seven natural enemies in association with pomegranate pests were also recorded. Among the different functional groups, phytophagous groups were dominated, followed by predators and parasitoids.
\end{abstract}

Keywords: Arthropod; Pomegranate; Deudorix Isocrates; Aphis punicae; Siphoninus phillyreae

\section{INTRODUCTION}

Pomegranate is one of the important fruit crops in India and is being cultivated in arid and semiarid regions of Gujarat, Maharashtra, Karnataka, Uttar Pradesh, Andhra Pradesh and Tamil Nadu (Balikai et al., 2011). India is the largest producer of pomegranate in the world. The total area under cultivation of pomegranate in India is $\mathbf{1 0 7 . 0 0}$ thousand ha and production is around 743.00 thousand tons. Although India is the largest producer, its productivity is only $6.9 \mathrm{MT} / \mathrm{ha}$. Totally 91 insects, 6 mites and 1 snail pest feeding on pomegranate crop havebeen reported in India (Verghese and Rashmi, 2014). The above reports confirmed that the commercially growing pomegranate farmers are facing several pest problems in their field, with no practical eco-friendly solutions. Further, to increase production and productivity, farmers are growing pomegranate under high density planting, which accommodates 1000 plants per hectare compared to 750 plants per hectare in the normal planting. Since the introduction of high-density planting in pomegranate is new, systematic study on the occurrence of pests under high density planting is wanting. Hence, to address the problem of pests under high-density planting with their natural enemies were studied in Tamil Nadu.

\section{MATERIAL AND METHODS}

Intensive field studies wereconducted during the year 2015 to 2016 for recording the insect pests and their natural enemies that are associated with pomegranate. The survey was carried out in four major pomegranate growing districts of Tamil Nadu viz., Coimbatore, Erode, Tiruppur and Karur (Table 1). In each district, minimum of threefarmer's fields were randomly selected and in field, ten plants were selected at random for observations on insect pests, natural enemies and type of damage. The insects were collected by hand picking and by using sweep nets from the study area. The young ones of the lepidopteran insect pests along with damaged flushes were collected in the study area, reared until their pupation and observed for the emergence of parasitoids if any. The predators and parasitoids collected from the study area during the survey were identified in the biocontrol laboratory, Department of Agricultural Entomology, Tamil Nadu Agricultural University, Coimbatore.

Table 1. List of villages surveyed in pomegranate growing districts of Tamil Nadu

\begin{tabular}{clr}
\hline District & \multicolumn{1}{c}{ Name of the village } & Geographical coordinates \\
\hline Coimbatore & Theethipalayam & $10.9694^{\circ} \mathrm{N}, 76.8956^{\circ} \mathrm{E}$ \\
& Thondamuthur & $10.9899^{\circ} \mathrm{N}, 76.8409^{\circ} \mathrm{E}$ \\
& Narasipuram & $11.2388^{\circ} \mathrm{N}, 76.9974^{\circ} \mathrm{E}$ \\
\multirow{5}{*}{ Erode } & Pazhamangalam & $11.1647^{\circ} \mathrm{N}, 77.8124^{\circ} \mathrm{E}$ \\
& Kalathuminra palayam & $11.1272^{\circ} \mathrm{N}, 77.7591^{\circ} \mathrm{E}$ \\
& Unjalur & $11.1283^{\circ} \mathrm{N}, 77.8772^{\circ} \mathrm{E}$ \\
& Sivagiri & $11.1179^{\circ} \mathrm{N}, 77.7881^{\circ} \mathrm{E}$ \\
& Kaara valasu & $11.1181^{\circ} \mathrm{N}, 77.7893^{\circ} \mathrm{E}$ \\
\multirow{6}{*}{ Tiruppur } & $11.0788^{\circ} \mathrm{N}, 77.8867^{\circ} \mathrm{E}$ \\
& Kodumudi & $10.4946^{\circ} \mathrm{N}, 77.2398^{\circ} \mathrm{E}$ \\
& Manupatty & $10.4845^{\circ} \mathrm{N}, 77.2973^{\circ} \mathrm{E}$ \\
& Elaiyamuthur & $10.9927^{\circ} \mathrm{N}, 77.0838^{\circ} \mathrm{E}$ \\
& Pallapalayam & $10.5201^{\circ} \mathrm{N}, 77.2570^{\circ} \mathrm{E}$ \\
& Thumbalapatti & $10.4347^{\circ} \mathrm{N}, 77.2915^{\circ} \mathrm{E}$ \\
& Kallapuram & $10.7616^{\circ} \mathrm{N}, 77.5806^{\circ} \mathrm{E}$ \\
& Kolathur palayam & $10.7202^{\circ} \mathrm{N}, 77.8900^{\circ} \mathrm{E}$ \\
& Pallapatti & $10.0110^{\circ} \mathrm{N}, 77.7927^{\circ} \mathrm{E}$ \\
& Vellapatti & $10.5724^{\circ} \mathrm{N}, 78.7862^{\circ} \mathrm{E}$ \\
\hline & Keeranur &
\end{tabular}

The farmers representing four districts of Tamil Nadu viz., Coimbatore, Erode, Tiruppur and Karur maintaining pomegranate under high-density planting were interviewed with the questionnaire. In addition, observations were also made during the survey in the pomegranate field to record the pest and their intensity 


\section{RESULTS AND DISCUSSION}

\section{Occurrence of pests and their natural enemies}

The incidence of pests was recorded periodically on pomegranate under high-density planting during the survey. The observation showed the presence of twenty-four pests in pomegranate under highdensity planting (Table 2).Among twenty-four pests, one belongs the order Coleoptera,ten from the order Hemiptera, nine from the order Lepidoptera, two in order orthoptera,one in order Acarina.

Table 2. List of pests associated with pomegranate under high density planting October 2015 - May 2016

\begin{tabular}{|c|c|c|c|c|}
\hline Common Name & Scientific name & Family & Order & Location \\
\hline Thrips & Scirtothrips dorsalis Hood & Thripidae & Thysanoptera & Coimbatore \\
\hline Aphids & Aphis punicae Passerini & Aphididae & Hemiptera & Tiruppur \\
\hline Two tailed mealy bug & Ferrisia virgata (Cockerell) & Pseudococcidae & Hemiptera & Erode \\
\hline Citrus mealy bug & Planococcus citri Risso & Pseudococcidae & Hemiptera & Coimbatore \\
\hline Whitefly & Siphoninus phillyreae Haliday & Aleyrodidae & Hemiptera & Tiruppur \\
\hline Hard scale & Diaspidiotus sp & Diaspididae & Hemiptera & Coimbatore \\
\hline Soft scale & Lepidosaphes punicae & Coccidae & Hemiptera & Coimbatore \\
\hline Tea mosquito bug & Helopeltis theivora Waterhouse & Miridae & Hemiptera & Coimbatore \\
\hline Scutellerid bug & Scutelleria nobilis & Scutelleridae & Hemiptera & Tiruppur \\
\hline Coreid bug & Cletus sp & Coreidae & Hemiptera & Tiruppur \\
\hline Red cotton bug & Dysdercus koenigiFabricius & Pyrrhocoridae & Hemiptera & Erode \\
\hline Two spotted spider mite & Tetranychus urticae Koch & Tetrenychidae & Acarina & Coimbatore \\
\hline Fruit sucking moth & Eudocimaphalonia(Clerck) & Noctuidae & Lepidoptera & Erode \\
\hline \multirow[t]{3}{*}{ Ash weevil } & $\begin{array}{l}\text { Myllocerus subfasciatus Guerin- } \\
\text { Meneville }\end{array}$ & Curculionidae & Coleoptera & Erode \\
\hline & Myllocerus viridanus Fabricius & Curculionidae & Coleoptera & Coimbatore \\
\hline & Myllocerus discolor Boheman & Curculionidae & Coleoptera & Coimbatore \\
\hline Castor semilooper & Achaea janata (Linnaeus) & Noctuidae & Lepidoptera & Coimbatore \\
\hline Tobacco cut worm & Spodoptera litura Fabricius & Noctuidae & Lepidoptera & Coimbatore \\
\hline Black hairy caterpillar & Euproctis fraterna (Moore) & Lymantriidae & Lepidoptera & Erode \\
\hline Tussock hairy caterpillar & Notolopus sp & Lymantriidae & Lepidoptera & Coimbatore \\
\hline Stem hairy caterpillar & Euproctis Iunata Walke & Lymantriidae & Lepidoptera & Karur \\
\hline Hairy caterpillar & Euproctis sp & Lymantriidae & Lepidoptera & Erode \\
\hline Slug caterpillar & Parasa lepida (Cramer) & Cochilididae & Lepidoptera & Coimbatore \\
\hline Grass hopper & Aiolopus strepens Latreille & Arctididae & Orthoptera & Coimbatore \\
\hline Wingless grasshopper & Neorthocris $s p$ & Arctididae & Orthoptera & Tiruppur \\
\hline Fruit borer & Deudorix Isocrates (Fabricius). & Noctuidae & Lepidoptera & Coimbatore \\
\hline
\end{tabular}

The natural enemies recorded during the survey in the pomegranate ecosystem are listed in Table 3 \& Fig. 1. The entomophages recorded against aphid, mealy bugs, whiteflies were Chilomenes sexamaculata Fabricius, Cryptolaemus montrouzieri Mulsant, Coccinella septumpunctata Linnaeus, Chrysoperla zastrowi sillemi (Esben-Petersen), Scymnus craccivora Ayyar and Mallada sp. The parasitoid found associated with castor semilooper was larval parasitoid Microplitis maculipennis Szepligeti. General predators like preying mantis and spiders were also found in pomegranate cropping. Similar observation on pomegranate was also reported by Ananda et al. (2009) in Karnataka. They highlighted the occurrence of thirteen sucking pests feeding on pomegranates. Hemiptera ( 8 species), thysanoptera (3 species) and two acarina pests. Likewise, the occurrence of 91 insects, 6 mites and one snail pest was documented on pomegranate (Balikai et al. , 2011). Karuppuchamy
(1994) reported on the presence of 15 insect species and four non insect pests of pomegranate. Butani (1979) reported that about 45 species of insects attack the pomegranate shrub. Jadhav and Ajri (1985) reported the sucking pests like thrips, aphids, mealy bugs, white flies, and mites from various part of India. About 100pests belonging to 12 orders and 38 families and 64 natural enemies of seven orders and 14 families were recorded on pomegranate orchards of Turkey (Ozturk and Ulusoy, 2009). In addition, 7 natural enemies were recorded associated with pomegranate pests under highdensity planting. Four from the family Coccinellidae and one each from Chrysopidae, Braconidae and Mantidae. Present observation on the association of natural enemies with pomegranate pest was also reported by Ananda et al. (2009) who reported five species from Coccinellidae, two from Mantidae and one each from Chrysopidae and Aphelenidae in the pomegranate eco system. 
Table 3. Natural enemies recorded in pomegranate

\begin{tabular}{|c|c|c|c|c|}
\hline Name of natural enemy & Stage of natural enemy collected & Family & Order & Host \\
\hline Menochilus sexmaculatus Fabricus & Grub and Adult & Coccinellidae & Coleoptera & Aphid,Mealy bug \\
\hline Cryptolaemus montrouzieri Mulsant & Grub and Adult & Coccinellidae & Coleoptera & Aphid,Mealy bug \\
\hline Coccinella transversalis Fabricus & Grub and Adult & Coccinellidae & Coleoptera & Aphid,Mealy bug \\
\hline $\begin{array}{l}\text { Chrysoperla zastrowi sillemi } \\
\text { (Esben-Petersen) }\end{array}$ & Grub and Adult & Chrysopidae & Neuroptera & Aphid, Whitefly \\
\hline Microplitis maculipennis Szepligeti & Pupa and adult & Braconidae & Hymenoptera & Castor semilooper \\
\hline Scymnus craccivora Ayyar & Grub & Coccinellidae & Coleoptera & Aphids, mealy bugs \\
\hline Praying mantis & Adult & Mantidae & Dictyoptera & Hairy caterpillars \\
\hline
\end{tabular}

\section{Assessment of farmer's perception on pests of} pomegranate under high-density

The data obtained from the survey on the occurrence of pomegranate pests and its natural enemies are presented in the (Table 4). Eighty per

cent of farmers expressed fruit borer Deudorix isocrates as the major pest, whereas86.6 per cent of farmers expressed fruit sucking mothOthreisfullonia as the major pest of pomegranate.

Table 4. Perception of pomegranate growers on the relative importance of major pests damaging pomegranate

\begin{tabular}{lrr}
\hline \multicolumn{1}{c}{ Pests } & *Farmer's responses (\%) & Order of relative importance \\
\hline Fruit borer Deudorix isocrates & 80 & Major \\
Fruit sucking mothOthreisfullonia & 86.66 & Major \\
Thrips Scirtothrips dorsalis & 70 & Major \\
Aphid Aphis punicae & 63.33 & Major \\
Two tailed mealy bug Ferrisia virgata & 73.33 & Major \\
Whitefly Siphoninus phillyreae & 60 & Major \\
Ash weevil Myllocerus subfasciatus & 36.66 & Minor \\
Castor semilooper Acheae janata & 43.33 & Minor \\
Two spotted spider mite Tetranychus urticae & 26.66 & Minor \\
\hline * Total
\end{tabular}

Among sucking pests, thrips (Scirtothrips dorsalis), aphid (Aphis punicae),two-tailed mealy bug (Ferrisia virgata) andwhitefly (Siphoninus phillyreae) were the major pests recorded and pomegranate whiteflies were identified based on the Martin(2004), which was supported by the responses $70,63.3,73.3$ and 60 per cent of the farmers, respectively.

Table 5. District - wise distribution of pests in pomegranate under high density planting and their level of infestation

\begin{tabular}{|c|c|c|c|c|c|c|c|c|c|c|c|c|c|c|c|c|c|c|}
\hline \multirow[t]{2}{*}{ Districts } & \multicolumn{2}{|c|}{$\begin{array}{l}\text { Deudorix } \\
\text { isocrates }\end{array}$} & \multicolumn{2}{|c|}{ Othreisfullonia } & \multicolumn{2}{|c|}{$\begin{array}{c}\text { Scirtothrips } \\
\text { dorsalis }\end{array}$} & \multicolumn{2}{|c|}{$\begin{array}{c}\text { Aphis } \\
\text { punicae }\end{array}$} & \multicolumn{2}{|c|}{$\begin{array}{l}\text { Ferrisia } \\
\text { virgata }\end{array}$} & \multicolumn{2}{|c|}{$\begin{array}{l}\text { Siphoninus } \\
\text { phillyreae }\end{array}$} & \multicolumn{2}{|c|}{$\begin{array}{l}\text { Myllocerus } \\
\text { subfasciatus }\end{array}$} & \multicolumn{2}{|c|}{$\begin{array}{c}\text { Acheae } \\
\text { janata }\end{array}$} & \multicolumn{2}{|c|}{$\begin{array}{c}\text { Tetranychus } \\
\text { urticae }\end{array}$} \\
\hline & $I^{*}$ & $\mathbf{S}^{*}$ & $I^{*}$ & $\mathbf{S}^{*}$ & $I^{*}$ & $\mathbf{S}^{*}$ & $1^{*}$ & $\mathbf{S}^{*}$ & $I^{*}$ & $\mathbf{S}^{*}$ & $I^{*}$ & $\mathbf{S}^{*}$ & $I^{*}$ & $\mathbf{S}^{*}$ & $I^{*}$ & $\mathbf{S}^{*}$ & $I^{*}$ & $\mathbf{S}^{*}$ \\
\hline Coimbatore & & $\mathrm{M}$ & & M & & $\mathrm{H}$ & & $\mathrm{H}$ & & M & & M & & $\mathrm{H}$ & & M & & $L$ \\
\hline Erode & & $\mathrm{H}$ & & $\mathrm{H}$ & & $\mathrm{H}$ & & L & & $\mathrm{H}$ & & $\mathrm{H}$ & & $M$ & & - & & $\mathrm{M}$ \\
\hline Tiruppur & & $\mathrm{H}$ & & $\mathrm{H}$ & & $\mathrm{H}$ & & M & & $\mathrm{H}$ & & $\mathrm{H}$ & & $\mathrm{H}$ & & $\mathrm{L}$ & & $\mathrm{M}$ \\
\hline Karur & & $\mathrm{H}$ & & M & & $\mathrm{H}$ & & $\mathrm{L}$ & & M & & $\mathrm{H}$ & & L & - & - & - & \\
\hline $\begin{array}{l}\text { Pest } \\
\text { Grade }\end{array}$ & \multicolumn{2}{|c|}{$\begin{array}{c}\text { Fruit } \\
\text { borer (\%) }\end{array}$} & \multicolumn{2}{|c|}{$\begin{array}{l}\text { Fruit sucking } \\
\text { moth(\%) }\end{array}$} & Thrips & \multicolumn{2}{|c|}{ Aphid } & \multicolumn{3}{|c|}{ Mealy bug } & Whitefly & \multicolumn{2}{|c|}{ Ash weevil } & \multicolumn{3}{|c|}{$\begin{array}{c}\text { Castor } \\
\text { semilooper }\end{array}$} & \multicolumn{2}{|c|}{ Mite } \\
\hline Low & \multicolumn{2}{|c|}{$<20$} & & $<20$ & \multicolumn{2}{|l|}{$<5$} & \multicolumn{2}{|l|}{$<5$} & \multicolumn{2}{|c|}{$<5$} & \multicolumn{2}{|l|}{$<5$} & \multicolumn{2}{|c|}{$<5$} & \multicolumn{2}{|c|}{$<5$} & & $<5$ \\
\hline Medium & \multicolumn{2}{|c|}{$21-40$} & & $21-40$ & \multicolumn{2}{|l|}{$6-10$} & \multicolumn{2}{|l|}{$6-10$} & \multicolumn{2}{|c|}{$6-10$} & \multicolumn{2}{|l|}{$6-10$} & \multicolumn{2}{|l|}{$6-10$} & \multicolumn{2}{|c|}{$6-10$} & & $6-10$ \\
\hline High & \multicolumn{2}{|c|}{$>40$} & & $>40$ & \multicolumn{2}{|l|}{$>10$} & $>10$ & & \multicolumn{2}{|c|}{$>10$} & $>10$ & & $>10$ & & $>10$ & 10 & & $>10$ \\
\hline
\end{tabular}

The other pests viz., ash weevil Myllocerus subfasciatus, castor semilooper Acheae janata, and non-insect pest,two-spotted spider miteTetranychus urticae recorded as minor pests in pomegranate under high density planting was similar to the opinion expressed by few farmers. Table 5. 
Represents the distribution of pomegranate pests under high density planting and their severity. The scores indicated that the level of infestation of fruit borer Deudorix isocrates and fruit sucking moth Othreisfullonia were high in pomegranate planting of Erode, Tiruppur and Karur districts of Tamil Nadu, Whereas the occurrence of thrips Scirtothrips dorsalis was high in all four districts.

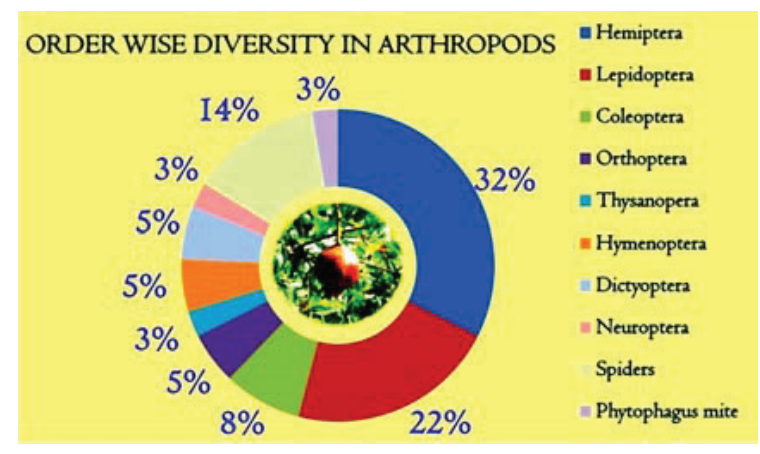

Figure 1. Insect order wise diversity in pomegranate under high density planting

The incidence of mealybug Ferrisia virgata was high in Erode and Tiruppur districts but low in Coimbatore and Karur districts. The damage by the aphids Aphis punicae was high in Coimbatore districts comparedto other districts. The whitefly incidence was high in Erode, Tiruppur and Karur but low in Coimbatore district. The occurrence of ash weevil Myllocerus subfasciatus was high in Coimbatore and Tiruppur districts. Regarding the incidence of castor semilooper Acheae janata, Coimbatore and Tiruppur showed the presence, whereas it was not recorded in Erode and Karur.The other pest noted during the survey was two-spotted spider mite Tetranychus urticae, whose incidence was low in Coimbatore as compared to the medium level of infestation noted in Erode and Tiruppur districts. The pest was not found in the Karur district

\section{CONCLUSION}

The above reports confirmed that the commercially growing pomegranate farmers are facing a number of pest problems in their field, with no practical eco-friendly solutions. Further, in order to increase production and productivity, farmers are growing pomegranates under high-density planting, which accommodates 1000 plants per hectare as compared to 750 plants per hectare in the normal planting. Since the introduction of high-density planting in pomegranate is new, systematic study on the occurrence of pests under high-density planting is needed.

\section{FUNDING AND ACKNOWLEDGMENT}

There is no funding, The authors are grateful to Dean, School of Post Graduate Study (SPGS), Director, Professor and Head, Department of Entomology and Central for Plant Protection Studies and Tamil Nadu Agricultural University for the help rendered during my research period.

\section{Ethics statement}

No specific permits were required for the described field studies because no human or animal subjects were involved in this research.

\section{Originality and plagiarism}

On behalf of all the authors, I assure that the work is original and the others works reported here are properly cited.

\section{Consent for publication}

All the authors agreed to publish the content.

\section{Competing interests}

There was no conflict of interest in the publication of this content

\section{Data availability}

All the data of this manuscript are included in the MS. No separate external data source is required. If certainly,thiswillbeextendedbycommunicatingwit hthecorresponding author through corresponding officialmail; elaento@gmail.com

\section{Author contributions}

$\begin{array}{llr}\text { Research grant } & - & - \\ \text { Idea conceptualization } & - & \mathrm{KE} \& \mathrm{SS} \\ \text { Experiments } & - & \mathrm{KE} \\ \text { Guidance } & - & \mathrm{SS} \\ \text { Writing-original draft } & - & \mathrm{KE} \\ \text { Writing- reviewing \& editing } & - & \mathrm{SS}\end{array}$

\section{REFERENCES}

Balikai, R. A., Y. K. Kotikal and P. M. Prasanna.2011. Status of pomegranate pests and their management strategies in India. Acta Horticulturae 890 : 569583.

Verghese, A and M. A. Rashmi. 2014. Netting in pomegranate to protect from fruit sucking moth. Insect Environment, 20(3): 100-102.

Anand N, Kotikal Y.K and Balikai R.A 2009. Management practices for major sucking pests of pomegranate. Karnataka J. Agric. Sci.,22 (4): 790-795.

Karuppuchamy, P.1994. Studies on the management of pests of pomegranate with special reference to fruit borer, Virachola isocratesFabr. Ph.D. Thesis, Tamil Nadu Agricultural University, Coimbatore, India.

Butani, D. K. 1976. Insect pests of fruit crops. Periodical Expert Book Agency, Delhi and International Book Distributiors, Dehradun.

Jadhav, S.S and Ajri D.S. 1985. Chemical control of scale insects on pomegranate in Maharashtra. Indian J. Ent.,4 (1) :63-65.

Ozturk, N and Ulusoy M.R. 2009. Pests and Natural Enemies Determined in Pomegranate Orchards in Turkey. Proceedings of first international symposium on Pomegranate, Acta Hort., 277-284. 